\title{
画像解析処理を利用した室内ダニの評価方法の確立とその展開 \\ DEVELOPMENT OF A HOUSE DUST MITE EVALUATION SYSTEM THROUGH IMAGE ANALYSIS AND ITS APPLICATION
}

\author{
山口 -*, 岡田 博**, 冨岡一之**, 竹内啓五** \\ Makoto YAMAGUCHI, Hiroshi OKADA, Kazuyuki TOMIOKA \\ and Keigo TAKEUCHI
}

\begin{abstract}
Today in Japan, with the homes built more air-tight and thermally insulated, they lack sufficient ventilation, causing higher humidity and increased condensation indoors. This type of environment fosters proliferation of mites, growth of fungi, and accumulation of house dust all allergens - causing residents living in such homes to suffer from allergy.

This report discusses a newly developed system that allows engineering evaluation of the activity of mites in order to maintain comfort in the human living space of homes and control mites, or the major indoor allergen in Japanese homes. Using an image processing technology, the system directly observes mites with its built-in camera and analyzes the observed behavior of those tiny mites and evaluates through a computer-based image processing, thereby providing engineering analysis of the influence of mites on chemicals, building materials, utilities, indoor environment, and building structure. This mite image processing system is designed to obtain a correlation between the analysis results obtained from the image data of mites and their activity and perform quantitative evaluation of the activity. It provides quick evaluation related to mites in the home environment, such as effect of mite-killing or -repelling chemicals, effect of different levels of temperature and/or humidity on mites, and the biology of mites in the home environment.
\end{abstract}

Keywords: mite, house dust, allegy, image analysis, indoor air quality, sick house

$$
\text { ダニ, ハウスダスト, アレルギー, 画像解析, 室内空気質, シックハウス }
$$

\section{1.はしめに}

近年、省エネルギーや快適な温熱環境の追求から、日本の建物は、 伝統的な通気性、通風性の高い建物から断熱・気密性の高いものへ と変遷してきた。特に、建材の規格化や精度の高い施工技術は、居 住・執務空間に高い気密性を確保させ、遮音・防音性、冷暖房のエ ネルギー効率などの優れた性能を施した。日本人は、1日の約 $80 \%$ を住宅やオフィスビルなどで過こしており、高気密・高断熱化され た構造物で適切な換気がされない場合、室内湿度の上昇、結露など の問題が生じ、ダニ・カビ・ハウスダストなどの室内生物污染粒子 および建材・開放型の暖房機器などから発生するホルムアルデヒド や揮発性有機化合物 (VOCs, Volatile Organic Compounds) などに よる問題が顕著化している ${ }^{1-4)}$ 。上記由来の気管支喘息、気管支炎、 過敏性肺炎、鼻炎、皮凬炎などのアレルギー疾患も年々増加する傾 向にあり、実際に日本人の約 $1 / 3$ が何らかのアレルギーに悩まさ れているという1)。

本報は、居住空間における快適性を維持し、日本における室内ア レルギーの主な原因であるダニに対する制御を目的に、画像処理技 術を応用し、ダ二活動度（ダ二数、ダ二活性など）を工学的に評価 できるシステムを開発した。具体的には、CCDカメラにより肉眼で は観察が困難であったダニを直接観察し、その挙動をコンピュータ で画像解析によって分析・評価することで、薬剤、建材、設備、室 内環境、建屋構造などのダニへの影響を工学的に分析するダ二画像 処理システムを確立した。これはダニの活動状況をカメラにより画 像で捉え、同画像情報より得た解析值とダ二の活動度との相関を導
き、その活動の度合を定量的に評価する方法である。種々の薬剤や 木材などにおける殺/防ダ二効果、種々の温湿度がダニの生態に及 ぼす影響、および実際の居住環境でのダニ生息が簡易に評価ができ るシステムである。

\section{2. 画像処理の原理と忘用}

居住空間での主要なアレルギーの原因物質 (アレルゲン) は、成 虫で体長が数百 $\mu \mathrm{m}$ の透明な体色のヒョウヒダ二類（チリダニ科） である。これまで肉眼で観察することがほとんど不可能なこの種の

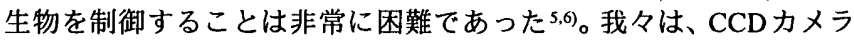
により観察したダニの活動映像を処理し、抽出された情報を時間的 かつ空間的に平均化することによって、その行動分析および評価が 可能になると考え、人の行動分析用に開発した手法の転用を検討し た ${ }^{7,8)}$ 。同方法は背景画像からの活動物体の抽出を基本原理とし、さ らに活動領域を累積して評価を行う。これにより対象物体が何処に どの程度の時間滞留していたなどの行動特性を視覚的に分析するこ とが可能である。また、計算はデジタル画像で行うため、滞留の程 度や密度 (個体数) の数值表現が可能である。計測対象は、移動（活 動）することが前提となるが、ダニは、安定した状況で活動が活発 で、その生命力が低下あるいは死滅するにつれ、活動するダニ数が 少なくなるので、測定対象に成りうると考えた。

\section{3. 実略材料ならひに実的方法}

3.1 供試夕ニと培養条件
* 清水建設(侏)技術研究所 主任研究員 - 理博

** 清水建設侏技術研究所 研究員
Senior Research Engineer, Institute of Technology, Shimizu Corporation, Ph. D. Research Engineer, Institute of Technology, Shimizu Corporation 


\subsection{1 供試ダニ}

我々が累代培養しているチリダニ (Pyroglyphidae) 科のヤケヒヨ ウヒダニ(Dermatophagoides pteronyssinus, $D p)$ とコナヒョウヒダニ (Dermatophagoides farinae, Df) を用いた（図1)。

\subsection{2 供試培地}

チリダニの純粋培養には、実験動物用飼料（日本クレア）と乾燥 醉母 (アサヒビール) を重量比で $1: 1$ に混合し、90 $90^{\circ} \mathrm{Cで} 30$ 分間乾 熱した後に、予め相対湿度 $75 \% \mathrm{RH}$ 前後に調整したインキュベータ 内で2、3日養生したものを用いた。培地は篩にかけることにより、 各々の粒径を数百 $\mu \mathrm{m}$ とダニと同様な大きさとした。

\section{1 .3 ダニ数の泪定}

MBA（メチレンブルー寒天、Methylene Blue Agar）法9に準じ、 ダ二培養物 $20 \mathrm{mg}$ を、0.2\%SDS (Sodium Dodecyl Sulfate、和光純

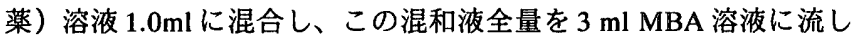
込んだ後、チリダニ培養物をメチレンブルー入りの寒天で固定化し、 実体顕微鏡下でその数を直接カウントした。

\section{2 画像撮影およひ処理}

\subsection{1画像解析处理システム}

図 1 に示した画像解析処理システムを使用した。マクロレンス (OVM-120Z、OLYMPUS) を通してCCDカラーカメラで撮影した 検体 (ダ二活動の様子)の映像は、一旦ビデオテープレコーダ(VTR (S-VHS VIDEO CASSETE RECORDER HR-X3SPT、VICTOR)) に 記録した。CCDカラーカメラを接続しているビデオマイクロスコー プ (OVM1000N、OLYMPUS) の各種設定を予め検討し、本研究に 最適な条件に調整した。検体の映像は、VTRから AD コンバータを 介して画像処理装置（PIP9000、ADS）に入力した。画像処理装置 はパソコン(PC9821、NEC)により制御され各種の処理を実施した。 なお画像は、 $512 \times 480$ 画素、256 階調である。

\subsection{2 画像処理}

画像からダニの数を安定に導く方法を検討した。画像の分析は、 背景画像の推定および入力画像と背景画像の差分抽出を基本に行う 7.8)。この処理によりダニの運動により変動が引き起こされた領域を 抽出することができる。この領域の面積はダニの数に応じて変化す ると仮定できる。しかし、ダ二の運動と培地の運動とが複雑に連動 するため、この領域の面積は時間的に摇らきを生じる。そこで抽出 した差分画像に二值化を施し、これに続く画像に対しても繰り返し、

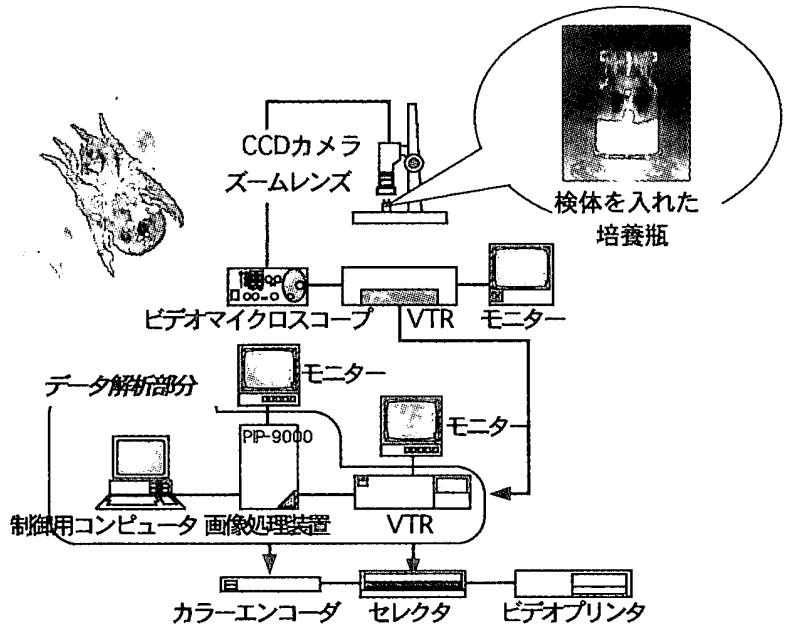

図 1 画像解析処理システム (左上写真 : ヤケヒョウヒダニ)
これらを累積することにより累積画像を作成した。累積を行うこと により、抽出領域の安定化ならびに単発的なノイス信号の相対的低 下が期待できる。差分・累積処理は画素単位で行い、抽出があった 画素に対し 1 を加算する。そして最終的に累積画像上の画素の值の 合計值を累積值として、ダニの数を評価するための指標と考えた。

背景画像自体はダニの運動により変化が予測されるため、適当 な時間間隔で更新する必要がある。そこで今回の処理においては、 背詈の推定は 20 秒間サンプリングした画像の加算平均を利用し、 差分抽出・累積処理に 40 秒間を設定し、これらを1サイクル好理 と考え、3サイクル処理を行うこととした。背景画像は 20 秒間に 64 枚の画像を入力し、それらの加算平均により推定した。累積処 理は 0.5 秒間隔で行い、全計測を通じ 240 回の累積を行った。な お、これらの時間設定は、実際の映像を事前に分析し、安定な抽 出が可能となる時間を実験的に求めたものである。

\section{3 防ダニ試唤}

\subsection{1 桼郕试駼}

$50 \mathrm{ml}$ 容プラスチック製遠沈管（CORNING、IWAKI GLASS）に、 希积飼料としてチリダニの純粋培養用培地を入れ、これに所定濃度 となるように、薬㖁 (粒状のものは乳鉢ですり潰す) を添加した。希 釈飼料と薬凨を均一に混合させるために、小型回転培養器（ロー テーターRT-50、TAITEC）にこの遠沈管をセットし、回転速度約 30r/minで一㡺夜連続運転して培地と薬剤を混合させた。

薬剤無添加のコントロールとしてチリダニの純粋培養用培地を用 いて同時に試験した。サンプル瓶は $5 \mathrm{ml}$ 容培養瓶（口径 $13 \mathrm{~mm}$ ）を 使用し、濃度調整した薬郕入り培地および約 1ケ月間培養した活動 度の高い供試ダ二培養物を計量スプーンすりきり一杯 $(550 \mathrm{mg})$ ず つ分注し、混合の後、紙栓で封をした。

このサンプルを温度 $25^{\circ} \mathrm{C}$ 、相対湿度 $75 \% \mathrm{RH}$ 前後に調整した恒温 槽（インキュベーター（冷凍機付）MIR-553 SANYO）に入れ、定 期的にダニ活動度を撮影するとともに目視観察した。また、ダニ挙 動によるデータのばらつきを考慮に入れ、実験は原則として 5 連の 系にて実施した。

防タニ性能は、以下に示した本論文の独自式によりダニ阻害率 （\%）を算出して、目視の結果と併せて各薬剤の効果を評価した。 ダニ阻害率 $(\%)=100$-(試験体の換算ダ二数* $\div$-コントロール の換算ダ二数）×100（*画像処理で導いたダ二数）

\subsection{2 木材試啀}

前もってチップ化した試験木材を、小型粉碎器（SCM-40型 柴 田科学器械(株)）にて、2分間粉砕した。粉砕した木材は種類によっ て、臭い、粉砕片形状などが明らかに異なる。 $50 \mathrm{ml}$ 容プラスチック 製遠沈管に、上述のチリダ二用培地と粉砕した木材を添加し (v/v)、 小型回転培養器（ローテーターRT-50）にて、回転速度を約 $30 \mathrm{r} / \mathrm{min}$ に設定して、一屋夜連続運転し、培地と混合させた。

調整した木材の分注、ダ二培養物の分注、試験体の培養などのそ の他の作業については、3.3.1 薬郕試験と同様に実施した。

\section{4 各種温度条件におけるダニの培善}

\subsection{1 所定温度におけるタニ培美容器}

$5 \mathrm{ml}$ 容ガラス製培養瓶に紙栓で封をしたものを使用した。

\subsection{2 温温度の䨋整}

温度は、タ二培養容器を収納した試験槽を恒温槽（3.3.1に記述） 
内に静置して $25^{\circ} \mathrm{C} に$ 保持した。また、ダニ培養容器を収納した試験 槽内の湿度は: 塩類飽和溶液調湿法 (常圧下) ${ }^{10}$ により調整した。こ の方法は、試料の吸放湿による湿度の変化が少なく、容器全体の温 度の変化に対しての相対湿度の変化が僅かであるという利点があっ た。

\subsection{3 温湿度のモニタリング}

所定の温湿度に試験槽内が保持されていることを確認するため、 各試験槽内に温湿度センサー（CHS-ATSおよびCHS-APS、TDK）を 設置し、バッファー（BUFFER AMP、スギヤマゲン）を通してデー タロガー（打点式ハイブリッド記録計 AA030-NGN、チノー）に出 カしてモニタリングした。

\subsection{4 画像解析值 (累積值) の統計処理}

ダニの活動（挙動）を撮影して得られた画像処理の生データであ る画像解析值 (累積值) は、供試ダ二の条件の標準化の困難さと撮 影感度の高さに起因する画像処理サイドのノイズを解消するために、 統計処理によるデータの補正を実施した。同条件で得られたデータ をトンプソン ${ }^{11}$ の棄却検定における一定信頼区間で検定した。検定 統計量 $\mathrm{T}\left(\mathrm{x}_{\mathrm{k}}\right)$ が自由度 $\mathrm{N}-2$ の $\mathrm{t}$ 分布に従うとし、 $\mathrm{T}\left(\mathrm{x}_{\mathrm{k}}\right)$ の絶対值を基準 にとび離れたデータとして棄却した。さらに、検定通過後のデータ から平均 $(\mathrm{x})$ 、標本分散 $\left(\mathrm{s}^{2}\right)$ および $\mathrm{t}$ 分布の表より自由度 $\mathrm{N}-1$ の $\mathrm{t}$ 分 布の $\alpha / 2 \mathrm{p}$ パーセント点を求め、正規母集団近似における一定信頼 区間を求めた。

\section{4. 実験結果ならひに考察}

\section{1 タ二数と画像解析值 (累樌值)}

人の行動分析用に開発した画像処理手法は、本研究の対象生物で あるダニの評価にも適用が可能であると考えられた ${ }^{12) 。 こ こ て ゙ は 、 ~}$ ダニの活動を捉えた映像を処理して求めた画像解析值および撮影に 供したサンプルのダニ数との間の相関関係を実験的に導いた。2ヶ月 間培養した $D p$ および $D f$ の培養物 $(30,000 \sim 40,000 匹 / 1 \mathrm{~g}$ 培養物） を新鮮な培地で段階的に希釈し、培地中に含まれるダ二数を調整し た。また Negative Control（0匹/1g 培養物）として、新鮮な培地を 用いた。CCDカラーカメラで上部よりダニの活動を撮影し、その映 像を画像解析処理した。実験は、ダ二数を調整した試料を $5 \mathrm{ml}$ 容培

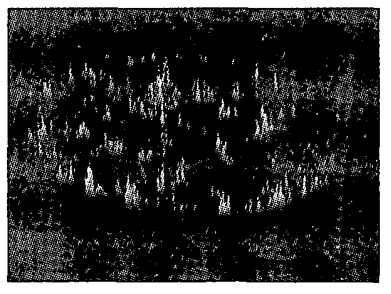

3,750 匹/1g培養物

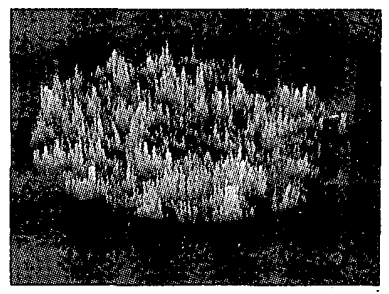

15,000 匹/1g培責物

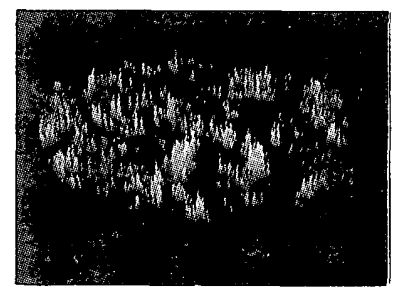

7,500 匹/1g培褰物

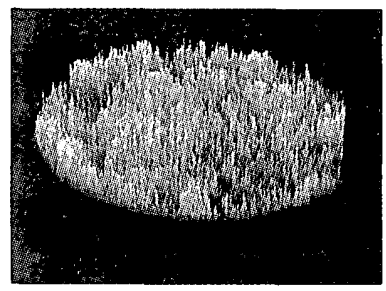

30,000 匹/1g培䪄物
図2 処理画像
養瓶に分注し、撮影および画像解析処理を実施した (3.3参照)。

\subsection{1 画像解析值}

画像解析值はダニの観測画像において、ダニの存在する領域を連 続して抽出し、その面積を評価した值である。抽出された領域の面 積は、観測領域内のダ二の数に応じて変化すると考えらるが、ダニ の運動が培地などにより埋もれた場合など、時間的且つ空間的に変 動することを考虑し、各時点での面積を累積し、最終的に得られた 累積面積を利用する。今回の計測においては、さらに評価値を無次 元化する意味で、累積回数での除算(時間平均化)、および領域面積 での除算(空間的平均化)を行い、最終的評価值とした。図 2 に、累 積の状態を、累積画像平面を拊瞰するように立体的に表現した画像を 示した。高さ方向は各画素に累積された累積の值を表している(3.2.2 参照)。累積の值が高いほど高くかつ白く示している。ダ二数が多い ほど全体的に累積の值が多くなっている様子がわかる。

\subsection{2 夕二数と画像解析值 (累䅡值) の相関}

測定したダ二数と画像解析值の関係は、3 次多項式近似によって その相関性が確認された（図3,4）。画像解析值とダ二数の相関は $\mathbf{R}^{2}$ 值で、Dpでは 0.9867、Dfでは 0.9558 と非常に高い相関性を示した。 これは、ダニのみの活動を画像として取り込むのでなく、全体のダ 二の活動を培地の動きと連動させ、培地を担体 (キャリヤー) とし て機能させたことによって (3.1.2参照)、サンプル毎の条件が均一 化したものであると考えられる。測定したダ二数と画像解析值の 3 次多項式の関係は、培養瓶中のダ二数の密度増加によるダ二相互間 の影響や、画像解析する対象がダニの動きだけでなく、連動する培 地を含めて解析しているからと考えられる。バックグラウンドノイ ズについては、ダニが不活性で 0 匹のサンプルを処理しても、得ら

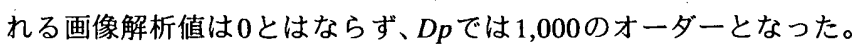
画像解析值を 0 に近づけるには、処理上の走查線のレベルなどを操

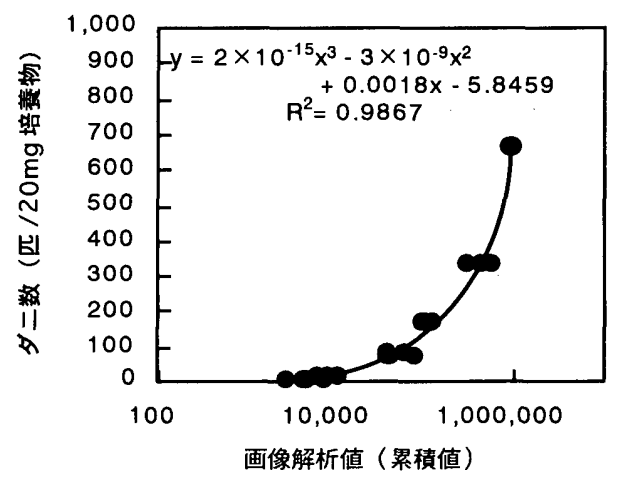

図 3 ダニ $(D p)$ と画像解析値との相関

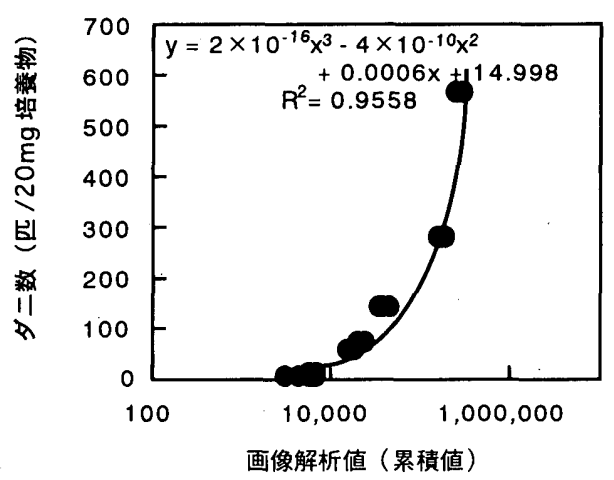

図 4 ダニ (Df) と画像解析值との相関 
表 1 薬剤の防ダニ性能評価

\begin{tabular}{|c|c|c|c|c|}
\hline $\begin{array}{c}\text { 培㮐時間 } \\
\text { 薬剂 }\end{array}$ & $\begin{array}{c}\text { 濃度 } \\
\text { (W/W\%) }\end{array}$ & $\begin{array}{c}1 \text { 週間 } \\
\text { 阻寒率 (\%) }\end{array}$ & $\begin{array}{c}\text { 2週間 } \\
\text { 阻害率 (\%) }\end{array}$ & $\begin{array}{c}\text { 4週間 } \\
\text { 阻害率 (\%) }\end{array}$ \\
\hline \multirow[t]{2}{*}{ 安息香酸 } & 1 & -21.4 & 3.4 & 28.8 \\
\hline & 10 & 96.4 & 101.0 & 99.8 \\
\hline \multirow[t]{2}{*}{ サリチル酸 } & 1 & 50.1 & 96.2 & 83.3 \\
\hline & 10 & 67.9 & 100.8 & 99.8 \\
\hline \multirow[t]{2}{*}{ p-ジクロロベンゼン } & 1 & -59.6 & -91.0 & 9.8 \\
\hline & 10 & 100.6 & 100.4 & 100.2 \\
\hline \multirow[t]{2}{*}{ テヒドロ酢酸 } & 1 & 101.1 & 99.8 & 100.1 \\
\hline & 10 & 101.5 & 100.5 & 100.1 \\
\hline \multirow[t]{2}{*}{ ナフタレン } & 1 & 101.0 & 100.8 & 97.5 \\
\hline & 10 & 101.7 & 101.0 & 100.3 \\
\hline \multirow[t]{2}{*}{ p-クロロ安息香酸 } & 1 & -40.5 & -62.5 & -7.9 \\
\hline & 10 & -39.0 & -25.8 & 57.5 \\
\hline \multirow[t]{2}{*}{ ほう酸 } & 1 & -3.0 & 24.3 & 44.1 \\
\hline & 10 & 41.5 & 95.3 & 99.0 \\
\hline \multirow[t]{2}{*}{ ヒノキチオール } & 1 & 83.0 & 92.0 & 96.5 \\
\hline & 10 & 99.5 & 98.3 & 99.0 \\
\hline
\end{tabular}

作、即ち画像認識ハードおよびソフトの改良によってある程度可能 になると考えられた。しかし、この検討は逆に感度の低下を伴う危 険性を孕んでいるため、非効率的であると判断した。Dfでも同様な 結果となり問題ないと判断した。さらに、画像処理時に影響を受け ると考えられるダ二挙動の撮影条件（色温度、自動感度、明度およ びランプ電圧) についても、一定值に設定してロットなどによる画 像解析值の変化を極力抑えることで、バックグラウンドノイスの影 響を、最終的には無視できると考えた ${ }^{13)}$ 。

\section{2 代表的防虫剂での防タ二性能評価}

ここでは既往研究にてその効果が明らかにされている防虫剂を含 む代表的な薬剤を選定し、画像処理適用の有効性を確認することと した。供試ダニには、実際の使用を想定して、薬剤に対し抵抗性が 高いとされている $D p$ を用いた ${ }^{14) 。 ~}$

表 1 に防ダ二試験結果を示す。主に、芳香族系の薬剤を実験に供 した。芳香族系などの薬剤については、最も防ダ二性に優れたもの はナフタレンおよびデヒドロ酢酸で、効果が確認された。p-ジクロ ロベンゼンおよび安息香酸については高濃度側（10\%）で効果が確 認された。さらに、サリチル酸では低濃度側（1\%)で効果を示した が、顕著な防ダ二効果は 2 週間後であった。p-クロロ安息香酸につ いては効果が確認できなかった。また、ほう酸については、1\%では 4週間後に若干の効果が確認され、10\%では1週間後に若干のダ二阻 害が、2 週間後からは強力な防ダ二性能が確認された。ヒノキチ才 ールについては、1\%でも1週間後から著しい防タ二性能を発揮して いた。

横井ら ${ }^{15)}$ は、コナヒョウヒダニ（Df）およびケナガコナダニに対 するナフタリン、p-ジクロロベンゼンおよびほう酸の增殖抑制効果 を顕微鏡観察によるダ二培養物と薬剤を混和した方法により調へて いる。それによると、コナヒョウニダニに対しては、ナフタリンは $1 \%$ で、 p- ジクロロベンゼンは $0.5 \%$ で速効的な効果を示し、ほう酸 は1\%で長期的な增殖抑制効果を認めた。我々の実験においては、ヤ ケヒヨウヒダニ $(D p)$ をターゲットとしており一概に比較はできな いものの、ナフタレンの傾向は同じであったが、p- ジクロロベンゼ ンについては $1 \%$ では 4 週間接触させても効果が現れず、10\%にて 1 週目に阻害率 $100 \%$ となり比較的早期に効果が現れるなど異なる 傾向を示した。ほう酸については $1 \%$ では 4 週間後も防ダ二効果は
若干（阻害率 $44.1 \%$ ）で、10\%では 2 週間後に阻害率 $95.3 \%$ と高い 防ダ二性を示し、Dp と比較し、Dfの方が薬剤に感受性が高い傾向 を示した。これは、その他の薬剤に関する既存の報告と一致した ${ }^{14)}$ 。

さらに、目視による観察結果と画像処理により算定した阻害率 （\%）の関係は、防ダ二試験法全般に見受けられる傾向として、阻害 率90\%以上においては、活動しているダ二はほとんど観察されない か皆無で、その活動度（活性）も非常に衰弱していた。阻害率60〜 90\%の範囲では活動しているダニの数が少ないかあるいは活動度が やや鈍化していた。一方、阻害率 50\%以下の範囲では目視での違い の判別は不可能だったため、ダニに対する微妙な効果の評価に、本 手法の有効性が示唆されたと考えた。

また、他の薬肪については、有機リン系、ピレスロイド系、およ びカーバメイト系なと防ダニ性能を有する薬剤についても、本画像 解析システムにより、顕著な薬効を観察している ${ }^{16,17)}$ (データ未提 出)。今後、住居内で長期間生活するヒトへの影響を最小にしつつ、 ダニばかりでなく、カビなどその他のアレルゲンへの対策が可能と なる薬㓮や天然剤などの選択・評価に対し、有効なッールとして役 立つと考えられる。

\section{3 無坛材での防タニ性能評価}

次に、建材の代表例として、無垢材の防ダ二性能を評価した。調 查した 22 種の木材すべてについて 1 日間、 1 週間、 1 力月間培養後 のサンプルの画像解析を行い、画像解析值よりダニの活動度の検討 を行った。各木材の解析結果を表 2 に示す。今回の測定では、サワ ラ、タイワンヒノキ、スギ、ベイヒ、レッドラワン、ヒバおよびヒ ノキの7種類について顕著な効果が認められた。

画像解析によると、最も早期に効果を示したのはサワラおよびべ イヒであり、培養 1 週間で、ダ二検体のいない Negative Control よ り若干高い画像解析值を示し、各々のダ二阻害率は $99.5 \%$ と $65.7 \%$ であった。 2 週間および 4 週間後には両者のサンプルは、ほとんど 活性を示さなかった。実体顕微鏡での観察でも、1 週間後、ダ二は あまり元気がなく、活動しているダ二は数匹程度であった。さらに、 2 週間および 4 週間後には、活動しているダニを発見することはほ

表 2 無垢木材の防ダ二性能評価

\begin{tabular}{|c|c|c|c|c|}
\hline No. & $\begin{array}{l}\text { 培覓時間 } \\
\text { 木ムク材 }\end{array}$ & $\begin{array}{c}\text { 1週間 } \\
\text { 阻害率 (\%) }\end{array}$ & $\begin{array}{c}2 \text { 週間 } \\
\text { 阻害率 (\%) }\end{array}$ & $\begin{array}{c}\text { 4週間 } \\
\text { 阻害率 }(\%)\end{array}$ \\
\hline 01 & トドマッ & 18.4 & 38.3 & 25.4 \\
\hline 02 & エソマッ & 41.2 & 26.5 & 18.5 \\
\hline 03 & カラマッ & 42.7 & -0.5 & 15.7 \\
\hline 04 & ラジアータパイン & 63.4 & 40.5 & 13.0 \\
\hline 05 & アカマッ & 79.4 & 55.8 & 50.2 \\
\hline 06 & サワラ & 99.5 & 101.6 & 99.9 \\
\hline 07 & ホワイトラワン & -11.4 & -24.8 & 36.4 \\
\hline 08 & ベイッガ & -9.4 & -7.0 & 41.6 \\
\hline 09 & スプルース & -6.5 & -25.9 & 30.9 \\
\hline 10 & ケヤキ & 22.4 & 31.2 & 57.6 \\
\hline 11 & タイワンヒノキ & 38.3 & 77.3 & 99.8 \\
\hline 12 & スギ & 36.9 & 90.3 & 98.6 \\
\hline 13 & レッドラワン & 51.9 & 56.8 & 94.0 \\
\hline 14 & アピトン & -9.5 & 26.4 & 31.6 \\
\hline 15 & ベィマッ & 63.8 & 54.9 & 23.2 \\
\hline 16 & チーク & 7.6 & 22.8 & 23.2 \\
\hline 17 & ベイヒ & 65.7 & 96.9 & 99.8 \\
\hline 18 & ブナ & -0.8 & 5.8 & 10.6 \\
\hline 19 & クリ & -27.6 & 5.8 & 35.2 \\
\hline 20 & ナラ & -3.9 & -1.8 & 27.5 \\
\hline 21 & ヒバ & 45.3 & 90.4 & 89.7 \\
\hline 22 & ヒノキ & 32.3 & 82.7 & 88.8 \\
\hline
\end{tabular}


とんどできなかった。サワラおよびベイヒに関しては、比較的速効 性の強い殺ダニ性が確認された。

次に、タイワンヒノキおよびスギでは、1 週間後に各々 $38.3 \%$ と $36.9 \% 、 2$ 週間後に各々 $77.3 \%$ と $90.3 \%$ の゙二阻害率が確認され、 4 週間後にはNegative Controlとほとんど同じ画像解析值を示した。目 視の場合、 1 週間後はダ二検体が元気に動き回っていたサンプルが、 2 週間後にはあまり元気がなくなり、4 週間後には活動している夕 二が数匹しか発見されなかった。タイワンヒノキおよびスギに関し ては徐々にダニに影響を与え培養 4 週間で致死に達するものと考え られ、遅効性の殺ダ二性効果が確認された。

レッドラワンでは、1 週間後に $51.9 \%$ 活性阻害、 2 週間後に 56.8 \%活性阻害、 4 週間後には $94.0 \%$ 活性阻害となった。実体顕微鏡で の観察でも、1 週間後にはサンプルに元気なく、2 週間および 4 週 間後には、その状態が継続していることを確認した。実際には、換 算匹数平均值が 1 週間目91.4匹、2週間目 170.4 匹、4週間目に 122.9 匹となり、強い防ダニ効果はないものの、増殖抑制効果を有してい ることが確認された。また、アカマツおよびケヤキでも、若干のダ 二活性阻害効果が認められた。

ヒバは、今回青森と地域指定した検体を使用し、強力な防ダ二性 を確認した。青森産でないヒバでは、 4 週間後に $29 \%$ ダニ活性阻害 と顕著な効果認められず、ヒノキについても、今回長野産で防ダニ 性能を確認できたが、ヒバと同様に産地によっては、防タ二性能を 殆ど示さないものもあった。全てのヒノキあるいはヒバに、防ダニ 効果はなく、同じ種類の木材でも、効能の違いを生じることが示 唆され、産地の違い、心材と辺材の相違、木材のロットによる違い、 試験方法の違いなど種々の理由が考えられた。

種々の植物精油（葉）はヒョウヒダニに対し行動抑制があり、ユ 一カリの強い抑制効果は、その主要構成成分に起因している ${ }^{18)}$ 。夕゙ 二を単に殺すだけでは、アレルギーの抗原性（アレルゲン性）の低 減は得られにくいか、薄荷油をコナヒョウヒダニに処理すると、抗

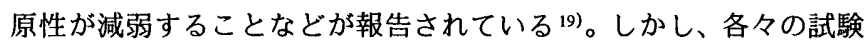
された精油の濃度は、高濃度であり、そのままでは実際の使用は困 難であると考えられる。すでに、サワラの樹皮成分には強い繁殖抑 制効果が存在すること ${ }^{20} 、$ 、ヒノキ、スギ、ベイヒバなどの木材が、 強い殺ダ二活性を持つことが報告されている21)。タイワンヒノキお よび青森ヒバなどについては天然抗菌物質であるヒノキチオールを 多く含んだ木材であることが知られている22)。4.2節「代表的防虫剂 での防ダニ性能評価」において、ヒノキチオールの防ダニ性が確認 されたが、今回の両木無垢材の防ダニ性についても主要な効果の一 つがヒノキチオールによるものと考えられる。

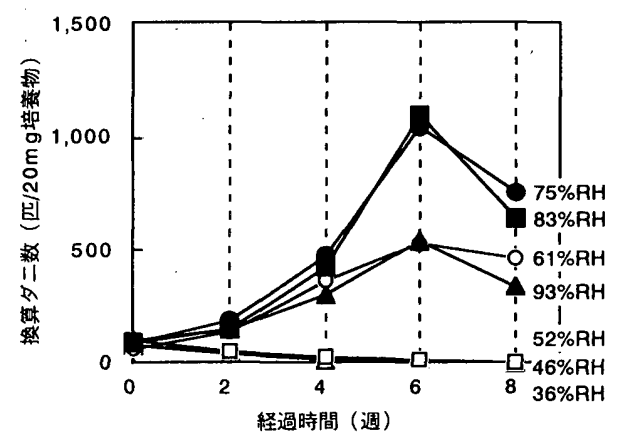

図 $5 D p$ 及ぼす湿度の影響（初期ダ二数 : 低）
薬剤や建材などの期待される効果として、生育抑制の他に、ダニ への忌避性もあるが、今回、この点についての検討はしなかった。 本報で開発した画像処理解析システム（図 1) は、ダ二の移動の軌 跡あるいは、その速度についても測定でき、ダニへの忌避性につい ての評価も可能である。

\section{4 タニの增殖ならひに活野に与える温度の影籍}

ダニの形態学的および生理学的特徵として、相対的に身体の表面 積が大きく、クチクラ層が未発達なため、体内の水分が失わされや すい構造になっていることがわかっている。したがって、室内のダ 二を制御するには、湿度コントロールが重要である ${ }^{23,24) 。 ~}$

既往の研究において、ダ二の最適温度・湿度を考察した場合、そ のほとんどがサーベイランスによる実際の建屋室内の実態調查から

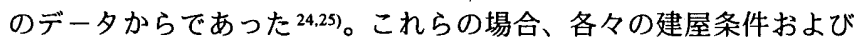
居住空間の環境状況の差も考えられ、単純に温湿度のダニへの影響 を把握することには問題があった。したがって、本報では、温度 25 ${ }^{\circ} \mathrm{C} に お け る$ 各種湿度条件を設定し、その雾团気下でダ二を培養し、 ダニの増殖および活動にどのような影響を及ぼされるかを検討した。 ラボスケール実験において、温湿度変化によるダニへの影響を把握 することは、一定の環境を保った状況下でのダニの長期培養やダニ の運動性および生物の誤差を鑑みた実験系の構築が必要となる。

尚、本報では、初期ダニ数を低く設定した場合と初期ダ二数を高 く設定した場合の 2 ケースについて検討した。前者は、少数のダニ が室内に侵入し增殖（ダ二数が増加）する場合を、後者は、既に室 内でダニが增殖した場合を想定した。室内へのダニの侵入は、通勤・ 通学時など人と人が接触し伝搬する場合や風などによる室外からの 飛来よると思われる ${ }^{26) 。}$

\subsubsection{Dpにおよほす温度の影暂 (ダ二初期数が低い埸合)}

定期的に測定したダニの活動度を表す画像解析值から、4.1.1で求 めた相関式を用いて、ダ二数に換算した結果を四 $5 に$ 示す。ここで は、累代培養した純粋 $D p$ 培養物を新鮮な培地で約10倍に希釈して、 その活動度を経時的に測定した。即ち、 $12 \mathrm{~g}$ の新鮮培地に $D p$ の力 月培養物 $1.2 \mathrm{~g}$ を添加し、この混合物 $550 \mathrm{mg}$ を $5 \mathrm{ml}$ 容培養瓶に添加し て紙栓にて封をした。この2力月培養物は、培養物 $1 \mathrm{~g}$ 当たり約 30,000 〜40,000匹のダニが含まれ、累代培養に使用している系における夕゙ 二密度がほほ最大に達していると考えられる。この測定では、 $61 \% \mathrm{RH}$ 以上の 4 種（61\%RH、75\%RH、83\%RH および93\%RH）の 培養条件において $D p$ の增殖が観察された。この中でも特に增殖が 促進され、高いダ二換算匹数を得たのは、75\%RH および83\%RHで あり、 $25^{\circ} \mathrm{C}$ における $D p$ の至適湿度は、80\%RH近傍にあると考えら れた。また、93\%RHにおいては、培養3週間目に培地内にカビの発

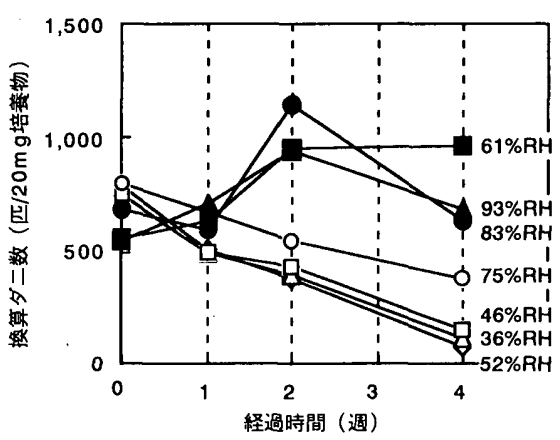

困 $6 D p$ 及ぼす湿度の影響（初期ダ二数 : 高） 


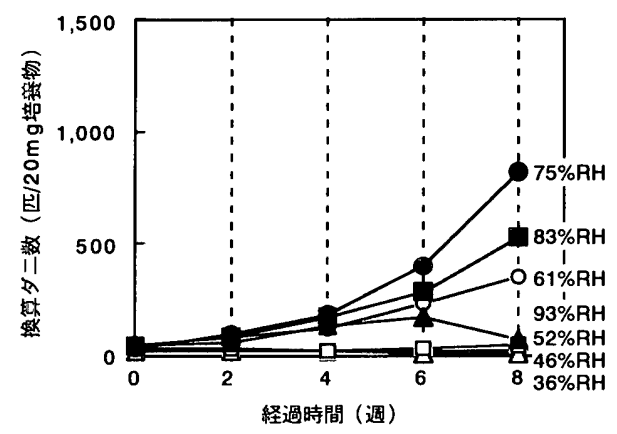

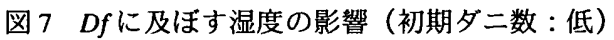

生が観察され、カビの增殖とダ二の増殖が拮抗し、ダ二の增殖は抑 制される傾向にあった。このカビは、形態学的な特徵から A spergillus 属と思われた。ここで、増殖数は多少抑えられるが、生 存ダ二個体の活動は活発であった。52\% R H 以下の低湿度条件 （36\%RH、46\%RH および52\%RH）では、Dpは増殖せず、実験開始 時の活動度が徐々に低下し、目視による観察では、3〜5週間後には 活動しているダニが全く存在しなくなった。さらに、83\%RH以上の 高湿度条件では、培地そのものが水分を吸着して団塊状になった。

\subsubsection{Dpにおよほす湿度の影㸷（ダ二初期数が高い場合）}

累代培養した純粋 $D p$ の 2 力月培養物（30,000〜 40,000匹/g培養 物）をそのまま実験に供した。図 6 に定期的に測定したダ二活動度 を表す画像解析值の統計処理後の結果を示す。この実験においては、 75\%RH以上の高湿度条件において、ダ二活動度が一定レベルに推移 した。この中で、93\%RHについては、4週間目にカビの発生が確認 され、培地の団塊化と併せて 5 週間目に活動度が大幅に減少した。 $52 \%$ RH以下の低湿度条件では、ダニ活動度を示す画像解析值は直線 的に減少し、4 週間目に 0 近傍に達した。61\%RHでは、ダニはその 活動度を維持することが出来ず、緩やかに画像解析值が減少した。

\subsection{3 湿度環境に対するダニの生態}

$D p$ と同様にDfにおよぼす湿度の影響を、ダ二初期数が低い場合 （図7）と高い場合（図8）について調査した。結果は、殆ど $D p$ と同 様であった。上記の4.4.1と4.4.2 の結果とまとめると、 $D p$ および $D f$ の增殖抑制ならびに活動抑制に顕著な効果を示す湿度条件は、 52\%RH以下の低湿条件で、これらの条件下においてはいずれのダニ の活動度やダニ数も最終的に0になるか非常に低いレベルに維持さ れた。また、增殖や活動パターンにダニ種間の相違が存在し、Dfが $D p$ に比べて若干低湿度側を好み、耐乾性を有していることが示唆さ れ、既往研究 23.24) と同様の結果を得た。

さらに、93\%RH条件下においては、いずれの実験ロットにおいて

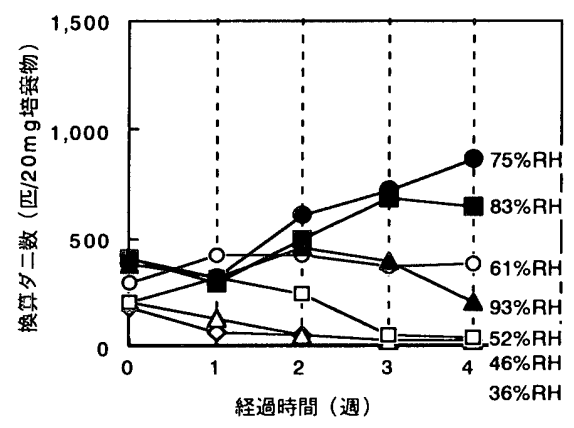

図 8 Dfに及ぼす湿度の影響（初期ダ二数 : 高）

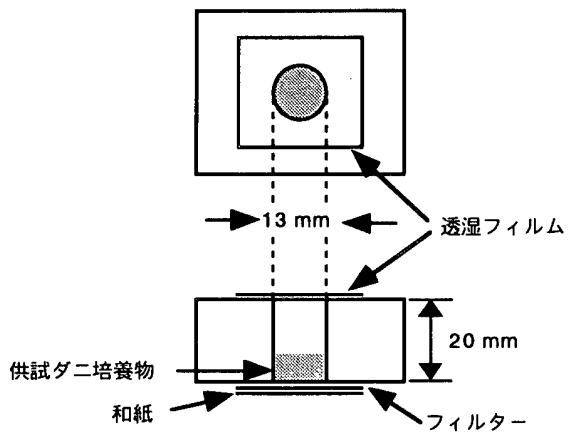

図 9 ダニセンサー

も培養開始数週間で A spergillus 属と思われるカビの発生が確認さ れ、以降はダニとカビの増殖が拮抗し、結果としてダ二数の増加が 抑制される傾向にあった。ダニとカビの関連については、ダニの消 化管から種々のハウスダスト由来の有機物に混じって微生物の菌系 と胞子、細菌などが発見されているので、ダニがカビを食している ことは間違いない。カビの存在がダ二の増殖を増長するという説も あるが、過度のカビの生育は逆にマイナスの作用をするとの報告も ある27)。

\section{5 ダニセンサーの開発}

前節までの測定系は、試験瓶に検体を入れ画像解析するシステム であり、建材や木材などの検体は破壊して検討しなくてはならず、 実際の建物での調查や建材・木材などの非破壊試験には不向きで あった。したがって、上記の問題を解決するため、ダニセンサーの 開発を実施した。ダニはカビと異なり、一箇所に固定して生息する わけでなく、始終移動し、適度な温湿度と慨となるハウスダストな どがなければ、生息できない。したがって、ダニセンサーを構築す るためには、ダニを幽閉し餌を添加したユニットと、湿気を透過し、 画像解析を実施するための透明な膜の使用が必須となる。

本報では、室内空間におけるダニアレルゲン抑制基盤手法として、 環境要因である温湿度や室内空気質などの室内環境因子の制御を前 提として、まず、チリダニの增殖ならびに活動にあたえる温度と相 対湿度の影響を、画像解析処理システム（図1) を利用して検討し た。

\subsection{1 ダニセンサーの構築}

図9に示すような系のセンサーを考案した。厚さ $20 \mathrm{~mm}$ のアクリ ルブロックに内径 $13 \mathrm{~mm}$ の穴を開け、下部を 200 メッシュフィル ターおよび和紙で覆い、供試ダ二培養物を添加した後、上部を透湿 フィルムで封をした。ダニセンサーに用いた各部材は予め単体でダ 二に接触させ、殺ダニ性・ダ二忌避性がないことを確認済みのもの を使用した。

$D p$ センサーの系における画像解析值とダ二数の相関について検討 した。2力月間培養した $D p$ を新鮮な培地でサンブル中のダ二数を調 整し（4.4.1 参照)、このダ二培養物 $1.0 \mathrm{ml}$ を先述のダニセンサーに 分注し、透湿フィルムで封をして上部よりダニ活動の模様を撮影し た。図10に画像解析值とダ二数をプロットし、3 次多項式により近 似した結果を示した。 $\mathrm{R}^{2}=0.9846$ となり、高い相関性が確認された。 $D f$ センサーの系における画像解析值とダ二数の相関について、Dp センサーと同様に検討した。図11に画像解析值とダニ数をプロット し、3 次多項式近似により求めた曲線と相関式を示した。この場合 も、 $\mathrm{R}^{2}=0.9846$ となり、高い相関性が確認された。 


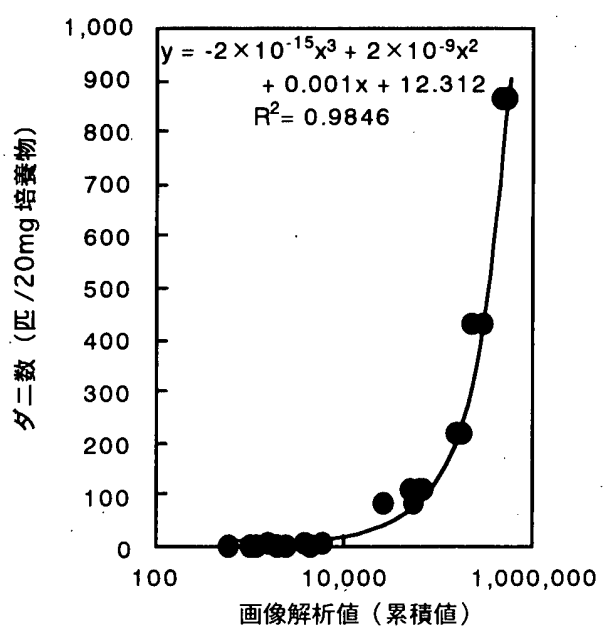

図 10 ダニ数と画像解析值との相関 $(D p$ センサー)

\subsection{2 ダニセンサーの耐久性}

センサーの耐久性試験を検討した。2 力月間培養したDpの培養物 を添加した、初期ダニ数が高いダニセンサーを温度 $25^{\circ} \mathrm{C}$ 、湿度 75\%RH前後に調整した雾囲気下に静置し、定期的にダ二活動度を撮 影した。図12に 1 週間毎に実測したダニ活動度の画像解析值と上記 で求めた相関式から換算した匹数の推移を示す。実験開始時、ダニ センサー内のダニの活動（画像解析值）は、4週（1力月）まで徐々 に減少したが、その後安定し 14 週（3.5力月）までほぼ一定のレべ ルに保持された。その後、再び減少を始めたダニの活動（画像解析 值）は、21 週（5.25力月）でかなり低いレベルまで低下した。ダニ センサーの寿命は、累代培養に用いている条件の雾囲気においては: 2 力月培養ダニを添加した場合、画像解析データや目視観察の結果 から 14 週（3.5力月）と判断した。この寿命はダニセンサーを設置 する環境の諸条件および添加ダ二培養物の增殖フェイズによって左 右されるが、環境評価のためのデー夕取得に必要な期間の使用には 十分耐え得る可能性を確認できたと考える。同じ系での $D f$ セン サー、および初期ダニ数が低い $D p$ および $D f$ ダニセンサー（4.4.1、 4.4.3）についても同期間での耐久性を確認した。

\subsection{3 タニセンサーによるタニへの温湿度影警の評価}

ダニセンサーを用いた、実際の建屋室内におけるダニの生息状況

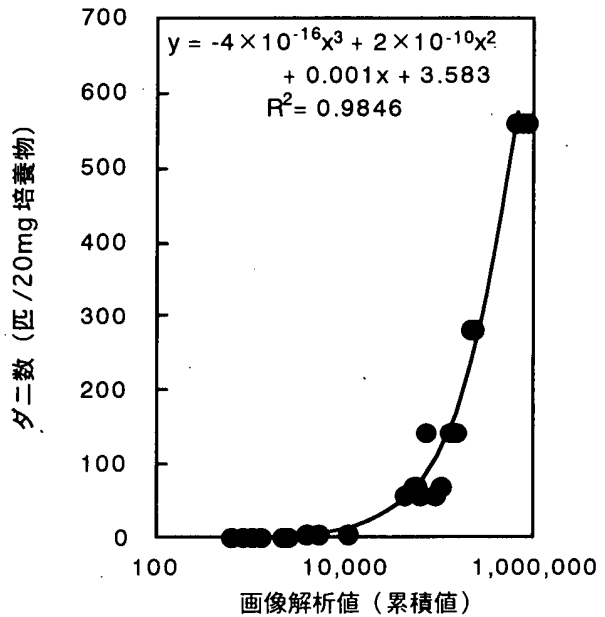

図 11 ダ二数と画像解析值との相関 (Dfセンサー)

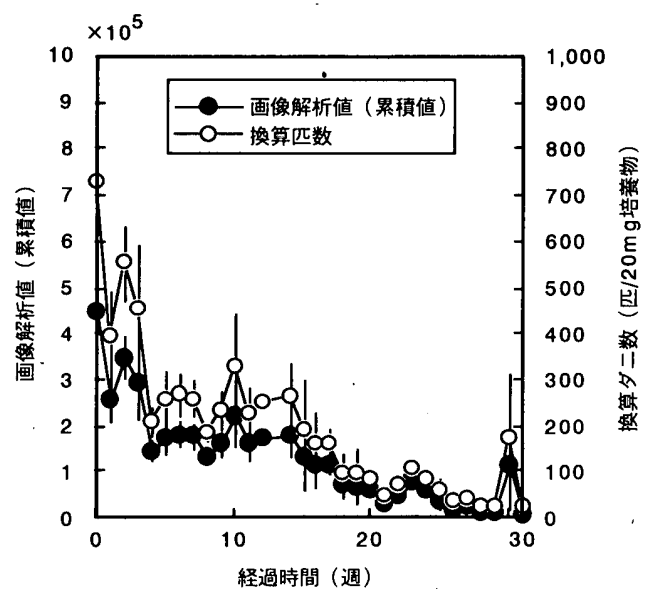

図 $12 D p$ センサーの画像解析值と換算ダ二数の経時変化

の調查法を確立するために、温度 $25^{\circ} \mathrm{C}$ における種々の相対湿度条件 （36\%、46\%、52\%、61\%、75\%、83\% および93\%RH）がダニにおよ ぼす影響について検討した。一例として、初期ダニ数が低い場合の Dfダニセンサーの結果を示した（図13）。ダニセンサーでの結果は、 4.4で実施した培養瓶での結果と同様な傾向を示した。 $D p$ および $D f$ に顕著な影響を示す湿度条件は、約 $52 \%$ RH 以下の低湿条件で、こ れらの条件下においては、いずれのダ二の活動度やダ二数も最終的 に0になるか非常に低いレベルに維持された。さらに、約 $93 \% \mathrm{RH}$ 条 件下においては、いずれの実験ロットにおいても培養開始数週間で カビの発生が確認され、以降はダニとカビの増殖が拮抗し、結果と してダニ数が㧕制される傾向にあった。また、増殖パターンにダニ 種間の相違が存在し、Dfが $D p$ に比べて若干低湿度側を好み、耐乾 性に優れていることが示唆され、4.4と同様の結果を得た。また、初 期ダ二数が高い場合も同様な結果が得られた。

ダニ活動度などの応答に要する期間に対して、試験系の違いによ る相違も存在した。ダニセンサーの系の方が試験瓶の系 (4.4.1 およ び4.4.4) と比較して数週間早く影響が出た。これは、両系の容量と 透湿・換気程度の違いなどに起因すると考えられる。

また、本研究開発の対象生物であるチリダニを指標生物の観点か ら捉え、環境評価モニタリングとしてダニセンサーの応用も考えら れる。ダニはその形態学的且つ生理学的特徵から、種々の環境条件 によって活動度や增殖速度が影響を受けやすい。当然、IAQ (Indoor Air Quality）に関連するホルムアルデヒドやVOCs および他の温湿 度要素に代表される環境因子などについてもその影響を受けること が予想される。さらに、このシステムは、ダニばかりでなくその他 の微細な生物に対しても、応用が可能であろう。

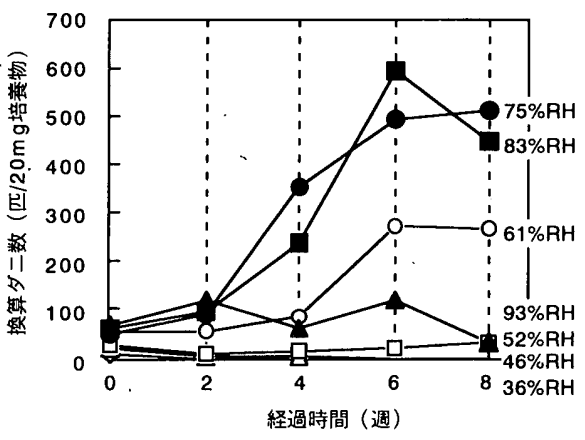

図 $13 D f$ センサーを用いた湿度影響の経時変化 


\section{5. まとめ}

現在まで、建材や薬剤のダニへの影響を調査するためには、培養 したダニ（ヒヨウヒダニあるいはコナダニなど）を所定のユニット に入れ、ダニの生死を観察する方法 (ドライフィルム法、クリップ 法や直接接触法など)、薬剤の忌避率を観察する方法 (公衛研法、侵 入阻止法、ガラス管法など）およびダ二の通過性試験などの手法が 報告されている ${ }^{28-30)}$ 。これらの方法は、ダ二の取り扱いに熟知した 研究者か、ダ二検体を一匹ずつ分離し、試験体のダニへの影響を、実 体顕微鏡などを通して、直接その数をカウントしたり、昆虫針で個 体を刺激して生死を判定するなど、専門的な技術および労力と時間 を要し、汎用性のある方法ではなかった。本報で開発した手法は、基 本的にダニ培養物を対象としているので、ダニと供試培地を分離す る必要がなく、一時に多数のサンプルを処理することも可能になっ た。さらに、厳密な意味での生死判定はできないものの、ダニの增 殖や活動を感度よく評価することができた。防ダ二試験や実際の室 空間での適用が可能になったことを考え併せると、室内ダニの制御 のための総合的な評価が可能になったといえる。

現在まで、都市計画、建物配置およびオフィス内配置などのヒト や自動車の動線分析に対して行ってきた画像解析を ${ }^{7.8) 、 タ ゙ ニ の よ う ~}$ な小動物に対して行い、工学的な手法を駆使し、その行動分析を可 能にした。この画像処理を利用したダニの評価手法は、今後、企画・ 設計、施工時の健康を配慮した建屋の建材、部材、設備、構工法な どの開発あるいは選択への展開を可能とするものであり、ダニなど のアレルゲン対策を施した健康配虑の建物構築のための第一段階で あるか、健康配虑の建物の実現のための有力な技術であると考えら れる。ダ二試験においては、Dfあるいは $D p$ のダニ種類、初期ダニ 数の高低など実施する試験方法により、試験結果は本質的に異なる ものではないが、全く一致した結果ではないと考えられる。した がって、本画像解析によるダニ試験においても、試験目的の明確化 と実施する試験方法を充分理解した上で活用するできである。

室内のダ二を抑制するには、住まい手の健康や安全性、効果の持 続性と経済性などを考虑し、換気などによる室内温湿度を制御し、 さらに防ダ二薬剤や防ダ二建材との併用効果についても検討するこ とが重要であろう。これについては、今回構築した測定・評価シス テムを応用すれば、困難なく必要な情報が把握できると考えられる。

一酸化炭素、二酸化炭素、ホルムアルデヒド、VOCsなどの室内 空気污染と比較し、ダニの発生は、特定の発生源はなく、人間が生 活するかきり、住宅のような一般的な建築物内では必ず起こり、強 力な薬剤使用などによりダ二を完全に死滅させることは、住まい手 である人間にも悪影響を与えることが照念される。したがって、ダ 二の抑制には、ダニを完全に防除するのでなく、アレルギー発生が 生じないレベルに制御することが重要となる ${ }^{31) 。 し た か ゙ っ て 、 タ ゙ ニ ~}$ の増加・增殖をいかに適正に抑えるかという視点での研究開発をこ れからも継続していく。

我々は、居住空間の快適性を維持し、主なアレルギーの原因であ るヒヨウヒダ二類（チリダニ科）のより効率的な制御および取り扱 いを目的として、ダニ画像解析処理システムを構築した。その結果、 以下に記す事項が明らかになった。

1 ) 活動度 (活性) の高いダ二の映像を処理した画像解析值（累積 值)とダ二数の間に高い相関性を見出した。画像解析值の利用は、ダ
二に対する微妙な影響を評価できる感度よい客観的手法である。

2 ) 本画像処理システムで、種々の薬剤および木材に関し防ダ二性 能を評価し、既往研究の比較から、その有用性を明らかにした。

3 ) 実際の室内を想定し、初期ダ二数が低い場合と高い場合におけ る湿度の影響やダニ種間の違いを明らかにした。

4 ) 実際の室空間や非破壊試験が可能な、タニセンサーによるダニ 影響試験方法を確立し、その性能を評価した。

5 ) この画像解析処理システムは、室内のダニばかりでなく、多く の微生生物の測定・評価にも応用が期待できる。

辟

本報告は、通商産業省「生活価値創造住宅開発プロジェクト」の「健康配感 技術の研究・開発に関する研究」に関する研究成果の一部である。

1) 高齐岡正敏、"ダ二室内塵の傾向とその対策”，MEDICAMENT NEWS No.1458,pp.16-17, 1994

2) 入江建久、“浮遊粉し人と生体環境”，空気調和・衛生工学, Vol. 72, No.5

3) 腮辺新一, ”室内化学污染”, 講談社, 1998

4) 吉川翠、阿部恵子、小蔁裕己、松村年郎、”室内污染とアレルギー”, 井上 書院, 1999

5) Okada,H., Yamaguchi,M., Minami,K. “Detection and Monitoring of Dust Mite" Proceedings of the 12 th International Symposium on Contaminaion Mite ,Proceedings of the $121 \mathrm{~h} 1 \mathrm{~s}, 1994$

6) Yamaguchi,M., Okada,H., Tomioka,K., Minami,K."Monitoring of Dust Mite" ,Proceedings of the 7th International Conference on Indoor Air Quality and Climate in Nagoya pp.687-692, 1996

7) 竹内啓五、長田耕治、“画像を利用した群集行動評価法に関する研究”、 清水建設研究報告, Vol.60, pp.123-131, 1994

8) 竹内啓五、山口二、岡田博、䈏岡一之、“快適摆境分析のための微小生物 壬三多に関する研究”, 日本建築学会学術講演梗概集, pp.721-722, 1996 9) 高岡正敏、山本德栄、浦辺研一中摆清明、久米并晃子、中山秀券、兴 井美佐、“室内塺加ら簡便夕"二検查法について”, 埼玉県衛生研究所報, No.1458, pp.64-69, 1990

10) 高分子と吸湿委貝会, 高分子学会、“材料と水分ハンドブック（吸湿、防 湿、調湿、乾燥 $)$, 共立出版, 1968

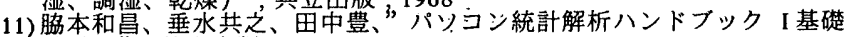
統計編”，共立出版，1991

12) 山口一、竹内鳘五、凬田博、冨岡一之: “画像好理によるダニアレルゲン 峝定評価システムの開発”, 空気調和・衛生工学会学術講演会講演論文集

13)山'年.969-972, 1996 岡田博、冨岡一之、“ダニアレルゲン画像処理システムの確立

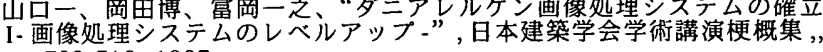
pp.709-710, 1997

14)渡辺富士雄、只木晋一、高岡正敏、石井正蔵、森本功、”精油の揮発成 分によるヤケヒョウヒ多にコナヒョウヒダニおよびケナガコナダニに 対する殺夕“効果”、生薬学雑誌, Vol. 43, pp.163-168, 1989

15) 横井寛昭、堀義宏、“コナヒヨウヒタ二およひケナガコナダに対するナ フ夕リン, p- ジク口ロベンゼンお゙よびウ酸の增殖抑制効果”, 名古屋市 衛生研究所報, No.39, pp.27-29,1993

16)中島芳明、今井長兵衛、夏原由博、“室内㦄性コナヒョウダ二Dermatophagoides farinae に対する fenthion,fenitrothion およひ permethrin $の$ 殺夕

17) 林晃史、"效しい害虫防除のテク生活衙生, No.34, pp.163-168, 1990

18) 宮崎良文、谷田貝光克、高岡正敏、”室内塵性夕和行動に及ぼす精油の

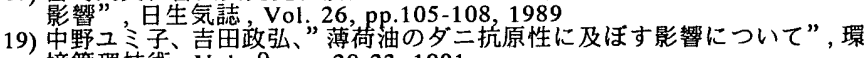
境管理技術，Vol.9 pp.20-23,1991

20) 近藤隆一郎、屋我嗣良、山田妙子、佐藤敏弥、谷田貝光克、”木材居住瓄 境ハンドブック、におい編”, pp.260-322, 岡野健他 8 名編集, 朝倉畫院,

21)谷田貝光克、”森林が放出する生物活性物質”, 日本環境動物昆虫学会, Vol. 5 , pp.83-89, 1993

22) 岡部敏弘、斎藤幸司、大友良光、”木材成分七ノキチオールの保存剤とし ての利用について”, 月刊フードケミカル, No. 5, pp.40-46, 1990

23) 松本克彦、岡本雅子、和田芳武、“コナヒョウヒダニ,ヤケヒョウヒダ二の

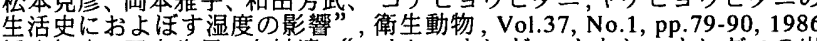

24) 橋本知幸、田中生男、上村清、“コナとヨウヒダニ,ヤケヒヨウヒダ二の出 現パ夕ーンに及ほす温湿度の影響”, 衛生動物, Vol.44, No.3, pp.185-195, 1993

25) 高岡正敏、藤本義典””室内塵夕二相と家屋の建築後年数（および增改築） の関連性について”, 艺レルギー, Vol. 34, pp.866-873, 1985

26) 吉川翠、芦澤達、山田雅士、”夕゙二・カビ・結露”, \#井上書院, 1995

27) 森田和矢、成隆光、幸形聡、山下雅司、吉田政弘、”多三の増殖におよほ 寸真菌の影響”，防菌防徽，Vol. 22, pp.545-548, 1994

28) 高橋正和、正野俊夫、梅原利之、”Pyridaben のクワガタッメダニ、コナ ヒヨウヒダニおよびケナガコナダニに対する殺ダニ効力ならび增殖抑制 効果”, 衛生動物, Vol. 41, pp.257-260, 1990

29) 森田傎一、容田貝光克、大平辰朗、”ヤクスキ土埋木へキサン抽出物の殺 夕“三と抗菌活性”，条材学会誌, ,Vol. 37, pp.352-357, 1991

30) 高橋正和、正野俊夫、梅原利之、"NC-194のコナヒヨウヒダニヤケヒョ ウヒダ秥よびケナガコナダニに対する增殖扣制効果”, 衛生動物, Vol.

31) 山只一、”、快適と健康性、ダ二”，建築雑誌，Vol. 114, pp.28-29, 1999

(2000年 7 月 4 日原稿受理, 2001 年 2 月23日採用決定) 